\title{
Determinan Stres pada Pegawai Kementerian Kesehatan Indonesia
}

\author{
Determinants of Stress among Civil Servants at Health Ministry of \\ Indonesia
}

Besral*, Winne Widiantini**

\begin{abstract}
*Departemen Biostatistik dan Kependudukan Fakultas Kesehatan Masyarakat Universitas Indonesia **Pusat Data dan Informasi Sekretariat Jenderal Kementerian Kesehatan Republik Indonesia
\end{abstract}

\begin{abstract}
Abstrak
Kejadian stres pada pelbagai kelompok di Indonesia cukup tinggi dan belum banyak diketahui determinannya. Penelitian ini bertujuan untuk mengetahui determinan stres pada pegawai Kementerian Kesehatan Republik Indonesia (Kemenkes RI). Penelitian potong lintang ini dilakukan pada tahun 2013 terhadap 230 pegawai sekretariat jenderal yang dipilih secara acak. Analisis statistik menggunakan regresi logistik ganda. Responden dikatakan stres jika memiliki skor 28 atau lebih dengan menggunakan 17 pertanyaan terkait personal stress inventory. Hasil penelitian menunjukkan prevalensi stres sebesar $79 \%$ dan determinan stres adalah obesitas, usia, jabatan, suku, pendidikan, dan aktivitas fisik. Risiko stres lebih tinggi pada pegawai yang obesitas $\left(\mathrm{OR}_{\mathrm{adj}}=1,9\right)$, pegawai berusia di bawah 40 tahun $\left(O R_{\text {adj }}=2,1\right)$, suku Sunda $\left(O R_{\text {adj }}=3,1\right)$, menduduki jabatan struktural $\left(O R_{a d j}=2,3\right)$, pegawai yang berpendidikan SMA atau D3 $\left(O R_{a d j}=2,8\right)$, dan pegawai perempuan yang kurang aktivitas fisik $\left(\mathrm{OR}_{\mathrm{adj}}=8,2\right)$. Disimpulkan bahwa determinan stres sangat bergantung pada beban kerja dan karakteristik individu, risiko stres sangat tinggi terdapat pada pegawai perempuan yang kurang aktivitas fisik. Disarankan agar Kemenkes melakukan promosi kesehatan tentang hidup sehat dan pencegahan stres kepada seluruh pegawai, melakukan rekreasi bersama secara berkala, melaksanakan olahraga rutin setiap hari Jumat pagi di pusat kebugaran Kemenkes untuk menurunkan obesitas dan stres.

Kata kunci: Aktivitas fisik, obesitas, stres
\end{abstract}

\section{Abstract}

The prevalence of stress on various groups in Indonesia is quite high and has not been known their determinants. This study aimed to find out determinants of stress among civil servants at the Health Ministry of Republic of Indonesia. This cross sectional study was conducted in 2013 toward 230 secretariat general civil servants selected randomly. Analysis of statistic used multiple logistic regression. Respondents were considered stress if they got score 28 or more by using 17 questions personal stress in- ventory. Results showed that prevalence of stress related to and determinants of stress were obesity, age, position, tribe, education and physical activity was worth $79 \%$. The risk of stress was higher among obese civil servants $\left(O R_{\text {adj }}=1.9\right)$, age under 40 years old $\left(O R_{a d j}=2.1\right)$, tribe Sundanese $\left(O R_{a d j}=3.1\right)$, structural positions $\left(O R_{a d j}=2.0\right)$, senior high school or vocation level $\left(\mathrm{OR}_{\mathrm{adj}}=2.8\right)$, women with lack of physical activity $\left(\mathrm{OR}_{\mathrm{adj}}=\right.$ 8.2). To sum up, determinants of stress very depended on work loads and individual characteristics, the highest risk of stress among women who lack of physical activity. The Health Ministry should promote health public concerning healthy lifestyle and prevention of stress to all civil servants, periodically holding recreation together, conducting regular exercise on Friday morning in order to reduce obesity and stress.

Keywords: Physical activity, obesity, stress

\section{Pendahuluan}

Kejadian stres masih tinggi dan sangat bervariasi pada berbagai kelompok di Indonesia. Hasil Riset kesehatan dasar (Riskesdas) tahun 2007 menunjukkan bahwa $11,6 \%$ penduduk Indonesia berusia 15 tahun ke atas mengalami gangguan mental emosional. Pada Riskesdas tahun 2013, angka tersebut menunjukkan penurunan menjadi 6\%.1,2 Hasil penelitian pada anggota majelis taklim di Jakarta Selatan menunjukkan bahwa prevalensi stres mencapai $13,3 \% .^{3}$

Hasil penelitian stres pada kelompok pekerja lebih tinggi daripada populasi umum, contohnya di Jakarta pada eksekutif muda kejadian stres mencapai 25\%.4 Sedangkan pada penderita penyakit kronis, kejadian stres

Korespondensi: Besral, Departemen Biostatistika dan Kependudukan FKM Universitas Indonesia, Gedung A, Lt. 2, Kampus Baru UI Depok, 16424, No.Telp: 021-7863473,e-mail: besral@yahoo.com 
lebih tinggi lagi, contohnya kejadian stress pada penderita stroke di Semarang mencapai $79 \% .^{5}$

Setiap pegawai berpotensi mengalami stres karena timbulnya stres berkaitan dengan interaksi perilaku, psikologis, dan biologis seseorang dalam hubungannya dengan sesama pekerja dan lingkungan kerjanya. Setiap pekerja akan mengalami interaksi dengan lingkungan dan terus akan terlibat dalam dinamika dan perkembangan organisasi. ${ }^{6}$

Pelbagai hasil penelitian menunjukkan dampak buruk dari stres pada pegawai, antara lain meningkatnya ketidakhadiran, rendahnya kepuasan kerja dan produktivitas kerja, meningkatnya angka kecelakaan kerja, kejadian hipertensi, penyakit jantung koroner, gangguan fisik dan mental, biaya akibat penyakit dan kecelakaan kerja terkait stres, pensiun segera, bahkan kejadian bunuh diri. $7-9$

Stres merupakan kondisi tertekan yang dialami oleh seseorang, dampak dari lingkungan kerja dan atau lingkungan psikososial yang merugikan individu tersebut. Gibson, ${ }^{10}$ menambahkan bahwa stres adalah suatu respon penyesuaian yang dimediasi oleh perbedaanperbedaan individu dan atau oleh proses psikologis dalam diri seseorang yang merupakan konsekuensi dari setiap tindakan apapun dari luar individu, lingkungan, situasi, atau peristiwa yang menyebabkan efek psikologis dan atau efek fisik yang berlebihan pada seseorang.

Stres juga dapat didefinisikan sebagai ancaman terhadap integritas fisiologis atau psikologis seseorang. Hal tersebut dapat menjadi nyata atau hanya ditafsirkan bahwa stres dapat menghasilkan respon fisiologis dan perilaku, baik respon yang baik maupun respons yang buruk. Dalam beberapa budaya timur, stres dilihat sebagai tidak adanya kedamaian batin. Di sisi lain, dalam beberapa budaya barat, stres dilihat sebagai hilangnya kontrol diri. ${ }^{11}$

Dapat disimpulkan bahwa stres merupakan pernyataan responden tentang kondisi faktor di luar dan di dalam pekerjaan yang dapat mengganggu keseimbangan psikologis, fisiologis, serta ditandai dengan gejala psikologis, gejala fisik, dan gejala perilaku. Respon stres dikaitkan dengan manifestasi dari pelbagai gangguan psikosomatik dan kejiwaan. Oleh karena itu, penting bagi kita untuk memahami mekanisme dasar yang memengaruhi gangguan psikosomatik dan kejiwaan tersebut.

Selain itu, antara laki-laki dan perempuan cenderung bereaksi secara berbeda dalam menghadapi stres, baik secara psikologis maupun secara biologis. ${ }^{12}$ Perbedaan ini juga perlu dipelajari dalam rangka untuk memiliki pemahaman yang lebih baik dalam hal perbedaan gender.

Kementerian Kesehatan Republik Indonesia (Kemenkes RI) adalah salah satu kementerian yang bertugas membantu Presiden dalam menyelenggarakan urusan pemerintahan di bidang kesehatan. Pegawai di Kemenkes RI telah sering dianjurkan untuk melakukan pengecekan kesehatan ke beberapa rumah sakit yang menjadi rujukan. Namun, masih banyak pegawai Kemenkes yang memiliki pola hidup kurang sehat, tidak mempraktikkan gaya hidup sehat dalam aktivitas seharihari, mengalami obesitas, dan mengalami stres. Penelitian ini bertujuan untuk mengetahui determinan kejadian stres pada pegawai di Kemenkes RI Tahun 2013.

\section{Metode}

Penelitian ini merupakan penelitian analitik dengan pendekatan kuantitatif menggunakan desain survei potong lintang, pengukuran variabel dependen stres dan variabel determinannya dilakukan pada waktu bersamaan. Pengumpulan data dilakukan pada bulan Mei hingga Juni 2013 melalui wawancara menggunakan kuesioner dan pengukuran status gizi oleh dua orang petugas yang telah dilatih.

Populasi pada penelitian ini adalah seluruh pegawai Sekretariat Jenderal Kemenkes RI yang berstatus Pegawai Negeri Sipil (PNS), yaitu sebanyak 1.119 pegawai. Kriteria inklusi adalah pegawai yang telah menjadi PNS minimal selama dua tahun dan kriteria eksklusi adalah pegawai yang memiliki masalah fisik (sakit atau cacat) serta pegawai yang sedang hamil. Penentuan besar sampel berdasarkan rumus pengujian hipotesis beda dua proporsi dengan menggunakan derajat kemaknaan 5\% dan kekuatan uji 90\%, maka sampel minimum yang dibutuhkan adalah 210 responden. Sampel pada penelitian ini adalah 230 pegawai yang dipilih secara acak sistematis.

Pengukuran berat badan menggunakan timbangan digital dengan ketelitian $0,1 \mathrm{~kg}$ dan pengukuran tinggi badan menggunakan meteran dengan ketelitian $0,1 \mathrm{~cm}$. Pengukuran aktivitas fisik dilakukan melalui wawancara menggunakan kuesioner Baecke. ${ }^{13}$

Pengukuran stres dilakukan dengan wawancara menggunakan kuesioner Personal Stress Inventory, yang merupakan modifikasi dari Hamilton Anxiety Rating Scale, menggunakan kuesioner 17 pertanyaan dengan tiga pilihan kategori jawaban, yaitu tidak pernah dengan skor 1 , jarang dengan skor 2 , dan sering dengan skor 3 untuk pernyataan negatif, sedangkan untuk pernyataan positif diberi skor terbalik. Ukuran yang digunakan untuk menentukan seseorang mengalami stres adalah jika total skor mencapai 28 atau lebih. ${ }^{14}$

Obesitas ditentukan berdasarkan ukuran antropometri berat badan dan tinggi badan, menggunakan indeks massa tubuh (IMT) yakni berat badan dalam kilogram dibagi dengan tinggi badan dalam meter kuadrat. Pengukuran IMT merupakan cara sederhana yang cepat dan mudah untuk memantau status gizi orang dewasa usia 18 tahun atau lebih. Cut off point IMT untuk orang Indonesia dimodifikasi oleh Kemenkes RI berdasarkan pengalaman klinis dan hasil penelitian di beberapa ne- 
gara berkembang. Kategori IMT untuk Indonesia adalah kurus (IMT < 18,5), normal (IMT 18,5 - 25,0), gemuk atau kelebihan berat badan atau obesitas (IMT $>25,0){ }^{2}$ Analisis regresi logistik ganda digunakan untuk membuat model determinan stres yang dikontrol oleh variabel karakteristik responden dan variabel perancu.

\section{Hasil}

Komponen stres berdasarkan 17 parameter ditampilkan pada Tabel 1. Masalah utama berkaitan dengan stres pada PNS Kemenkes RI adalah pola makan tidak teratur $(85 \%)$, cepat lelah $(78 \%)$, bertengkar dengan pasangan $(72 \%)$, sulit tidur $(69 \%)$, merasa tegang atau tidak nyaman $(68 \%)$, merasa pegal dan sakit yang tidak jelas $(63 \%)$, merasa lemah, letih, atau lesu tanpa sebab (63\%), dan membuat banyak kesalahan dalam pekerjaan $(62 \%)$

Hal lain dalam dalam komponen stres yang relatif cukup baik adalah komponen kebahagiaan. Sebagian besar responden merasa bahagia, hanya 36\% melaporkan merasa tidak bahagia. Setengah dari responden memiliki rasa humor yang baik, dan mereka merasa mampu menyelesaikan pekerjaannya. Namun, setengah dari responden juga melaporkan sering atau terkadang bertengkar dengan teman-temannya atau dengan anggota keluarga mereka. Menggunakan skor 28 atau lebih tinggi sebagai indikasi adanya stres, didapatkan bahwa 79\% dari PNS Kemenkes RI pada tahun 2013 mengalami stres.

Berdasarkan karakteristik responden, terlihat bahwa sebagian besar responden berusia 31 - 50 tahun $(72 \%)$, berjenis kelamin laki-laki (54\%), sebanyak $48 \%$ responden mengalami obes, posisi sebagai staf ( $89 \%)$, berpen-

Tabel 1. Komponen Stres pada PNS

\begin{tabular}{lc}
\hline Personal Inventory Stress & $\%{ }^{*}$ \\
\hline Pola makan saya tidak teratur & 84,8 \\
Saya merasa cepat lelah & 77,8 \\
Saya bertengkar dengan pasangan saya & 71,7 \\
Saya susah tidur, atau sering terbangun waktu tidur & 69,1 \\
Selama ini saya merasa tegang/tidak tenang & 68,3 \\
Saya merasa pegal dan sakit yang tidak dapat saya & \\
gambarkan dengan jelas & 62,6 \\
Saya merasa lemah/letih/lesu tanpa sebab yang jelas & 62,6 \\
Saya membuat banyak kesalahan dalam pekerjaan & 62,2 \\
Saya merasa lambat menyelesaikan pekerjaan & 59,6 \\
Saya mengalami masalah dalam pekerjaan & 57,0 \\
Segala sesuatu berjalan sebagaimana semestinya (\% tidak) & 57,0 \\
Kualitas hasil pekerjaan saya kurang baik & 56,5 \\
Saya bertengkar dengan teman-teman saya & 52,6 \\
Saya bertengkar dengan anggota keluarga saya & 51,3 \\
Saya merasa tidak mampu menyelesaikan pekerjaan saya & 48,7 \\
Saya mempunyai rasa humor yang baik (\% tidak) & 48,7 \\
Saya merasa bahagia (\% tidak) & 36,5 \\
\hline Skor $\geq 28$ (mengalami stres) & $\mathbf{7 9 , 1}$ \\
\hline
\end{tabular}

Keterangan : *\% menjawab Ya, sering atau kadang-kadang didikan sarjana (46\%), suku Jawa (53\%), dan memiliki indeks aktivitas fisik yang sedang (36\%).

Tabel 2 menunjukkan risiko stres menurut variabel determinannya, yang menampilkan nilai odd ratio (OR) crude (bivariat) dan OR adjusted (multivariat). Obesitas merupakan salah satu faktor risiko terjadinya stres, risiko stres pada kelompok yang obes lebih tinggi dibanding kelompok yang tidak obes. Kejadian stres pada kelompok obes mencapai $82 \%$, sedangkan pada yang tidak obes hanya $75 \%$. Kelompok yang obes memiliki risiko hampir dua kali lebih besar untuk mengalami stres dibandingkan yang tidak obes (OR adjusted 1,9 ).

Kejadian stres bervariasi menurut kelompok usia. Semakin muda usia, risiko stres semakin tinggi. Kejadian stres pada kelompok usia di bawah 31 tahun mencapai $83 \%$, pada usia 31 - 40 tahun mencapai $81 \%$, pada usia 41 - 50 tahun berkurang menjadi $77 \%$, dan pada kelompok usia 51 tahun kejadian stres hanya 74\%. Kelompok usia 40 tahun atau lebih rendah memiliki risiko 2 kali lebih besar (OR adjusted 2,1) untuk mengalami stres dibandingkan dengan kelompok usia 50 tahun atau lebih.

Kejadian stres berbeda menurut jenis kelamin, perempuan memiliki kejadian stres yang lebih tinggi dibandingkan laki-laki. Kejadian stres pada perempuan mencapai $81 \%$, sedangkan pada laki-laki kejadian stres hanya $77 \%$. Perempuan memiliki risiko 1,2 kali lebih besar untuk mengalami stres dibandingkan dengan laki-laki. Hubungan ini tidak bermakna secara statistik, namun analisis interaksi menunjukkan bahwa efek jenis kelamin terhadap kejadian stres berbeda menurut aktivitas fisik, atau ada interaksi antara jenis kelamin dengan aktivitas fisik dalam risiko terjadinya stres.

Kejadian stres juga berbeda menurut posisi atau jabatan, kejadian stres lebih tinggi pada staf atau pejabat struktural dibanding nonstaf. Kejadian stres pada jabatan struktural mencapai $80 \%$, sedangkan pada staf nonstruktural kejadian stres hanya $68 \%$. Pejabat struktural memiliki risiko 2,3 kali lebih besar untuk mengalami stres dibandingkan dengan non struktural.

Kejadian stres bervariasi menurut tingkat pendidikan. Semakin rendah tingkat pendidikan, semakin tinggi risiko stres. Kejadian stres pada kelompok pendidikan tamat Sekolah Menengah Atas (SMA) mencapai 81\%, pada kelompok pendidikan diploma mencapai $86 \%$, pada kelompok pendidikan sarjana mencapai $80 \%$, dan pada kelompok pascasarjana kejadian stres hanya $67 \%$. Kelompok pendidikan SMA atau diploma memiliki risiko masing-masing 2,8 kali dan 2,4 kali lebih besar untuk mengalami stres dibandingkan dengan kelompok pendidikan magister.

Kejadian stres berbeda menurut ras atau suku bangsa, suku sunda memiliki risiko lebih besar untuk mengalami stres. Kejadian stres pada Suku Sunda mencapai 91\%, sedangkan pada suku lainnya kejadian stres hanya ber- 
Tabel 2. Determinan Stres pada PNS

\begin{tabular}{|c|c|c|c|c|c|c|c|c|c|}
\hline \multirow{2}{*}{ Variabel } & \multirow{2}{*}{ Kategori } & \multirow{2}{*}{$\frac{\text { Normal }}{\%}$} & \multirow{2}{*}{$\begin{array}{c}\text { Stres } \\
\%\end{array}$} & \multicolumn{2}{|c|}{ Total } & \multirow{2}{*}{ OR crude } & \multirow{2}{*}{$95 \% \mathrm{CI}$} & \multirow{2}{*}{$\mathrm{OR}_{\mathrm{adj}}$} & \multirow{2}{*}{$\mathbf{9 5} \% \mathrm{Cl}$} \\
\hline & & & & $\mathbf{n}$ & $\%$ & & & & \\
\hline \multirow[t]{2}{*}{ Obesitas } & Tidak & 24,5 & 75,5 & 110 & 47,8 & 1,0 & & & \\
\hline & Ya & 17,5 & 82,5 & 120 & 52,2 & 1,5 & $1,0-2,4$ & 1,9 & $1,1-3,1$ \\
\hline \multirow[t]{4}{*}{ Usia } & $\leq 30$ tahun & 17,1 & 82,9 & 41 & 17,8 & 1,7 & $0,7-4,1$ & 2,1 & $0,7-5,7$ \\
\hline & $\overline{3} 1-40$ tahun & 19,3 & 80,7 & 83 & 36,1 & 1,5 & $0,7-3,2$ & 2,0 & $0,8-4,8$ \\
\hline & $41-50$ tahun & 22,9 & 77,1 & 83 & 36,1 & 1,2 & $0,6-2,5$ & 1,6 & $0,7-3,8$ \\
\hline & $51+$ tahun & 26,1 & 73,9 & 23 & 10,0 & 1,0 & & & \\
\hline \multirow[t]{2}{*}{ Jenis kelamin } & Laki-laki & 22,6 & 77,4 & 124 & 53,9 & 1,0 & & & \\
\hline & Perempuan & 18,9 & 81,1 & 106 & 46,1 & 1,3 & $0,8-2,0$ & 1,2 & $0,7-1,9$ \\
\hline \multirow[t]{2}{*}{ Jabatan } & Nonstruktural & 32,0 & 68,0 & 25 & 10,9 & 1,0 & & & \\
\hline & Struktural & 19,5 & 80,5 & 205 & 89,1 & 1,9 & $1,0-3,7$ & 2,3 & $1,0-5,1$ \\
\hline \multirow[t]{4}{*}{ Pendidikan } & SMA & 19,0 & 81,0 & 58 & 25,2 & 2,1 & $1,0-4,0$ & 2,8 & $1,3-6,3$ \\
\hline & D3 & 14,3 & 85,7 & 28 & 12,2 & 2,9 & $1,2-7,0$ & 2,4 & $0,9-6,7$ \\
\hline & Sarjana & 19,6 & 80,4 & 107 & 46,5 & 2,0 & $1,1-3,6$ & 1,4 & $0,7-2,8$ \\
\hline & Magister & 32,4 & 67,6 & 37 & 16,1 & 1,0 & & & \\
\hline \multirow[t]{4}{*}{ Suku } & Lainnya & 26,3 & 73,7 & 38 & 16,5 & 1,1 & $0,5-2,4$ & 1,1 & $0,4-2,7$ \\
\hline & Jawa & 22,3 & 77,7 & 121 & 52,6 & 1,2 & $0,7-2,3$ & 1,3 & $0,7-2,5$ \\
\hline & Sunda & 9,3 & 90,7 & 43 & 18,7 & 3,5 & $1,4-8,5$ & 3,0 & $1,2-7,7$ \\
\hline & Betawi & 25,0 & 75,0 & 28 & 12,2 & 1,0 & & & \\
\hline \multirow[t]{3}{*}{ Aktivitas fisik } & Ringan & 10,3 & 89,7 & 78 & 33,9 & 3,3 & $1,7-6,2$ & 3,6 & $1,8-7,1$ \\
\hline & Sedang & 25,6 & 74,4 & 82 & 35,7 & 1,1 & $0,6-1,8$ & 1,0 & $0,6-1,7$ \\
\hline & Berat & 27,1 & 72,9 & 70 & 30,4 & 1,0 & & & \\
\hline
\end{tabular}

Keterangan: *OR adjusted dikontrol oleh variabel demografi dan variabel potensial perancu lainnya (usia, jenis kelamin, pendidikan, obesitas, jabatan, suku, dan aktivitas fisik)

kisar $74 \%$ sampai $78 \%$. Suku Sunda memiliki risiko tiga kali lebih besar untuk mengalami stres dibandingkan dengan Suku Betawi, Jawa, atau lainnya.

Kejadian stres juga bervariasi menurut tingkat aktivitas fisik. Semakin rendah tingkat aktivitas fisik, semakin tinggi risiko stres. Kejadian stres pada kelompok aktivitas fisik ringan mencapai $90 \%$, pada kelompok aktivitas fisik sedang mencapai $74 \%$, dan pada kelompok aktivitas fisik berat kejadian stres hanya 73\%. Kelompok aktivitas fisik ringan memiliki risiko 3,6 kali lebih besar untuk mengalami stres dibandingkan dengan kelompok aktivitas fisik berat.

Efek jenis kelamin untuk mengalami stres dimodifikasi oleh aktivitas fisik atau ada interaksi antara jenis kelamin dengan aktivitas fisik dalam hubungannya dengan kejadian stres. Tabel 3 menyajikan risiko stres pada perempuan dibandingkan dengan laki-laki, yang dikelompokkan berdasarkan aktivitas fisik. Hasil penelitian ini menunjukkan bahwa perempuan yang memiliki aktivitas fisik ringan memiliki risiko 8 kali lebih besar untuk mengalami stres dibandingkan dengan laki-laki. Perempuan yang memiliki aktivitas fisik sedang atau berat, memiliki risiko stres yang hampir sama dengan laki-laki.

\section{Pembahasan}

Penelitian ini menunjukkan bahwa prevalensi stres di kalangan PNS Kemenkes RI cukup tinggi (79\%) dibandingkan dengan penelitian lain di Indonesia. ${ }^{1-3}$ Tingginya prevalensi ini mungkin disebabkan oleh adanya perbedaan metode dan alat ukur. Penelitian ini menggunakan
Tabel 3. Risiko Perempuan Dibandingkan Laki-laki untuk Mengalami Stres Menurut Aktivitas Fisik

\begin{tabular}{llll}
\hline Variabel & Kategori & OR $_{\mathbf{a d j}^{*}}$ & $\mathbf{9 5 \% \mathbf { C I }}$ \\
\hline Aktivitas fisik & Ringan & 8,2 & $1,8-38,5^{* * *}$ \\
& Sedang & 1,0 & $0,2-4,7$ \\
& Berat & 0,6 & $0,1-2,7$ \\
\hline
\end{tabular}

Keterangan:

*OR adjusted dikontrol oleh variabel demografi dan variabel potensial perancu lainnya (usia, pendidikan, obesitas, jabatan, suku, dan aktivitas fisik)

**Nilai $\mathrm{p}<0,001$

alat ukur personal stress inventory yang dimodifikasi untuk mengukur stres. ${ }^{9}$ Kejadian stres pada PNS Kemenkes RI ini menyamai kejadian stres pada penderita stroke, yakni sebesar $76 \%$, meskipun studi yang dilakukan pada penderita stroke menggunakan alat ukur Depression Anxiety Stress Scale 42 (DASS 42) untuk mengukur stres. 4

Kejadian stres dapat berdampak pada buruknya status kesehatan. Schneiderman menyatakan bahwa stres memiliki pengaruh besar pada suasana hati, kebahagiaan, perilaku, dan status kesehatan. Respon stres yang akut pada anak remaja atau pada orang yang sehat mungkin biasa saja dan tidak memiliki pengaruh pada kesehatannya. Namun, jika ancaman stres tersebut berlangsung dalam waktu yang lama tanpa henti (kronis), terutama pada orang dewasa atau orang yang tidak sehat, pengaruh jangka panjang dari stres dapat merusak kesehatannya. Intervensi psikososial perlu dilakukan untuk mengurangi gangguan akibat stres dan mencegah munculnya 
penyakit tidak menular, seperti hipertensi dan jantung pembuluh darah. ${ }^{5}$

Kejadian stres sangat bervariasi menurut karakteristik demografi usia, jenis kelamin, dan tingkat pendidikan. Hasil penelitian ini sejalan dengan penelitian Baumeister yang menyatakan bahwa risiko stres dan gangguan mental lebih tinggi pada kelompok jenis kelamin perempuan, kelompok yang tidak menikah, tidak bekerja, dan memiliki status sosial ekonomi yang rendah. ${ }^{15} \mathrm{Hal}$ ini sejalan dengan penelitian Widagdo, ${ }^{16}$ yang menyatakan bahwa risiko terjadinya stres dan gangguan mental berbeda menurut usia, jenis kelamin, pendidikan, dan pekerjaan serta penyakit kronis yang dialami.

Tingginya risiko stres pada kelompok pendidikan menengah dibandingkan dengan pendidikan tinggi (sarjana dan magister) dapat terjadi karena bagi mereka yang berpendidikan rendah memiliki keterbatasan dalam pola coping terhadap permasalahan-permasalahan yang dialami. Namun, mereka yang berpendidikan tinggi memiliki kemampuan dan pengetahuan yang lebih baik sehingga berdampak pada kemampuan mengatasi persoalan hidup dan cenderung lebih mampu mengatasi permasalahan, sehingga risiko untuk mengalami stres lebih rendah. ${ }^{15}$

Tingginya prevalensi stres mungkin berkaitan dengan beban kerja yang tinggi atau jam kerja yang berlebihan, hal ini terlihat dari kejadian stres pada pegawai yang menduduki jabatan struktural lebih tinggi dibandingkan dengan kejadian stres pada pegawai staf nonstruktural. Walaupun pada penelitian ini tidak dilakukan pengukuran beban kerja, namun beban kerja pegawai yang menduduki jabatan struktural lebih lebih tinggi dibandingkan dengan staf nonstruktural. Stres yang berlebihan dapat meningkatkan risiko timbulnya gangguan kesehatan, menyebabkan penurunan produktivitas, dan berdampak secara signifikan terhadap penurunan kinerja secara keseluruhan. Sebuah penelitian di Inggris menunjukkan bahwa prevalensi stres pada guru kepala sekolah di West Sussex meningkat dibandingkan dengan para pekerja lainnya. Tingginya beban kerja merupakan penyebab utama terjadinya stres pada guru kepala sekolah tersebut. Jenis kelamin dan tipe sekolah juga berpengaruh terhadap kejadian stres, kepala sekolah perempuan memiliki stres lebih tinggi daripada rekan laki-laki mereka. ${ }^{17}$

Hasil penelitian ini juga sejalan dengan penelitian Ireton, 18 yang melakukan penelitian tentang stres pada pasien yang melakukan skrining dan evaluasi kesehatan keluarga. Mereka menemukan bahwa sekitar 15\% dari pasien ini prihatin dengan pernikahan mereka, mengalami masalah seksual atau kebiasaan pribadi lainnya (makan, minum, merokok, istirahat, olahraga). Selain itu, dilaporkan bahwa mereka mengalami tingkat stres yang cukup tinggi dan kecemasan berlebihan. Pasien dengan gangguan psikologis menunjukkan tingkat stres yang lebih tinggi, kecemasan, depresi, kemarahan, dan ke- bingungan serta rendahnya dukungan emosional dan keterampilan dalam mengatasi masalah (coping skill). Pasien psikosomatis mengalami depresi yang lebih berat, kemarahan, dan kebingungan, serta mendapatkan dukungan emosional yang lebih rendah daripada rekanrekan mereka yang sakit secara fisik.

Setiap individu membawa karakteristik tertentu dalam bekerja dan karakteristik individu ini akan menentukan bagaimana individu tersebut akan merespons terhadap stres. Respons individu terhadap stres dipengaruhi oleh pelbagai faktor termasuk karakteristik individu, tipe kepribadian, dukungan sosial, jenis kelamin, usia, rasa harga diri, dan rasa efikasi diri. ${ }^{19}$ Akibatnya, respon terhadap stres sangat bervariasi dari orang ke orang dan sangat tergantung pada interaksi yang kompleks antar kepribadian mereka, nilai-nilai, keterampilan, dengan situasi kondisi saat itu. ${ }^{20}$

Kejadian stres berbeda menurut jabatan, hasil penelitian ini menunjukkan bahwa pejabat struktural memiliki risiko yang lebih besar untuk mengalami stres. Hasil ini sejalan dengan penelitian Mkumbo, ${ }^{21}$ yang menemukan bahwa tiga faktor yang signifikan berhubungan dengan stres, yaitu kurangnya keterlibatan pegawai dalam proses manajemen kelembagaan, kurangnya sistem pendukung yang diperlukan berkaitan dengan pekerjaan mereka, dan tingginya beban kerja. Pegawai yang berkualitas dan menduduki jabatan yang lebih tinggi melaporkan tingkat stres yang lebih tinggi pula.

Kejadian stres berhubungan dengan manifestasi dari pelbagai gangguan psikosomatik dan gangguan kejiwaan. Oleh karena itu, penting untuk memahami mekanisme yang mendasari dan memengaruhi hubungan ini. Selain itu, laki-laki dan perempuan cenderung bereaksi berbeda terkait stres, baik reaksi secara psikologis maupun biologis.

Penelitian ini menunjukkan bahwa perempuan yang kurang aktivitas fisiknya memiliki risiko 8 kali lebih tinggi untuk mengalami stres dibandingkan dengan laki-laki. Pada perempuan yang memiliki aktivitas fisik sedang atau berat, risiko mengalami stres hampir sama dengan laki-laki. Perbedaan ini perlu digali lebih dalam agar didapatkan pemahaman yang lebih baik. Pemahaman ini akan memiliki dampak yang signifikan terhadap upaya pencegahan stres pada laki-laki dan perempuan. Misalnya, dengan mengadakan rekreasi bersama staf Kemenkes ke pelbagai tempat dan lokasi yang disukai oleh laki-laki dan perempuan. Dapat pula disediakan pelbagai sarana yang menyesuaikan dengan kebutuhan lakilaki dan perempuan untuk dapat mencegah stres, pada perempuan dapat disediakan sarana arisan di kantor sehingga mereka memiliki sarana untuk saling bercerita dengan teman sekerja. Selain itu, sarana olah raga (pusat kebugaran) yang berada di Kemenkes sebaiknya dapat digunakan secara maksimal oleh semua pegawai Kemenkes 
dengan membuat jadwal penggunaan yang teratur setiap minggunya.

Selain pencegahan, perlu dilakukan upaya untuk mengurangi risiko stres yang sudah terjadi. Palos dan Viscu, ${ }^{22}$ melaporkan bahwa kecemasan psikologis berkorelasi positif dengan pikiran negatif, sementara gangguan penerimaan diri berkorelasi negatif dengan kecemasan psikologis dan kecemasan somatik serta dengan pikiran negatif. Upaya intervensi untuk mengurangi risiko stres yang dilakukannya melalui dukungan dan konseling telah terbukti mampu menyebabkan berkurangnya tingkat kecemasan dan stres, mampu mengubah kemampuan adaptasi (coping skill), dan secara signifikan dapat meningkatkan kualitas hidup pegawai.

Pada penelitian ini, determinan stres yang diteliti hanya terbatas pada karakteristik sosiodemografi pegawai saja, belum dilihat determinan stres yang terkait dengan beban kerja, perilaku kerja, dan lingkungan kerja. Perlu dilakukan penelitian lebih lanjut untuk mengeksplorasi pengaruh dari beban kerja, perilaku kerja, atau lingkungan kerja terhadap kejadian stres pada PNS Kemenkes RI.

\section{Kesimpulan}

Prevalensi stres pada PNS Kemenkes cukup tinggi, yakni $79 \%$. Determinan stres pada PNS Kemenkes adalah obesitas, usia lebih muda, pejabat struktural, Suku Sunda, pendidikan di bawah magister, dan perempuan yang aktivitas fisiknya rendah.

Risiko stres pada pegawai yang obes 2 kali lebih tinggi dibanding pegawai yang tidak obes, risiko stres pada pegawai berusia di bawah 40 tahun 2 kali lebih tinggi dibandingkan usia 41 tahun atau lebih, risiko stres pada suku Sunda 3 kali lebih tinggi dibanding suku lainnya. Pegawai yang menduduki jabatan struktural memiliki risiko stres 2 kali lebih tinggi dibandingkan dengan staf biasa. Pegawai berpendidikan sarjana atau lebih rendah memiliki risiko stres 2 kali lebih tinggi dibandingkan yang berpendidikan magister. Pegawai perempuan yang kurang aktivitas fisiknya memiliki risiko stres 8 kali lebih tinggi dibandingkan dengan laki-laki.

\section{Saran}

Disarankan kepada Kemenkes RI untuk melakukan promosi kesehatan tentang hidup sehat dan pencegahan stres kepada seluruh pegawai, melakukan kegiatan rekreasi bersama secara berkala, melakukan olahraga rutin sebagai salah satu kegiatan fisik setiap hari Jumat pagi menggunakan fasilitas olah raga (pusat kebugaran) di Kemenkes RI untuk menurunkan obesitas dan stres.

Dibutuhkan perencanaan yang lebih baik dan intervensi yang terprogram untuk seluruh pegawai Kemenkes RI agar mampu beradaptasi dan mengatasi stres dalam kehidupan mereka. Penelitian lebih lanjut perlu di- lakukan untuk mengeksplorasi pengaruh lingkungan kerja terhadap stres.

\section{Daftar Pustaka}

1. Departemen Kesehatan. Riset Kesehatan Dasar (Riskesdas) 2007. Jakarta: Badan Penelitian dan Pengembangan Kesehatan, Departemen Kesehatan Republik Indonesia; 2008.

2. Kementerian Kesehatan. Riset Kesehatan Dasar (Riskesdas) 2013. Jakarta: Badan Penelitian dan Pengembangan Kesehatan, Kementerian Kesehatan Republik Indonesia; 2013.

3. Fitriani, Anna. Kondisi sosial ekonomi dan stres pada wanita hipertensi anggota Majelis Taklim. Kesmas: Jurnal Kesehatan Masyarakat Nasional. 2012; 7 (5): 214-8.

4. Kamso S, Purwantyastuti, Lubis DU, Juwita D, Robbi YK, Besral. Prevalensi dan determinan sindrom metabolik pada kelompok eksekutif di Jakarta dan Sekitarnya. Kesmas: Jurnal Kesehatan Masyarakat Nasional. Oktober 2011; 6 (2): 85-90.

5. Adientya G, Handayani F. Stres pada kejadian stroke. Jurnal Nursing Studies. 2012; 1 (1): $183-8$.

6. Koenig HG, Vandermeer J, Chambers A, Burr-Crutchfield L, Johnson J. Minor depression physical outcome trajectories in heart failure and pulmonary disease. Journal of Nervous and Mental Disease. 2006; 194(3): 209-17.

7. Malgorzata, Chojnacka, Krzysztof Witkowski. Determinants of stress in the company perfecting quality. Management. 2012; 16 (1): 36-50.

8. Dhania, Dhini R. Pengaruh stres kerja, beban kerja terhadap kepuasan kerja pada medical representatif di Kota Kudus. Jurnal Psikologi Universitas Muria Kudus. 2012; 1 (1): 15-23.

9. Schneiderman N, Gail Ironson, and Scott D. Siegel. Stress and health: psychological, behavioral, and biological determinants. Annual review of clinical psychology. 2005; 1: 607-28.

10. Gibson RS. Principles of nutritional assesment. New York: Oxford University Press; 2005.

11. De Vogli Roberto. Socioeconomic deteriminants of healthy lifestyles: Does psychosocial stress matter? [dissertation]. Los Angeles: University of California; 2003.

12. Verma R, Balhara YP, Gupta CS. Gender differences in stress response: Role of developmental and biological determinants. Industrial Psychiatry Journal. 2011; 20: 4-10.

13. Baecke JA, Burema J, Frijters JE. A short questionnaire for the measurement of habitual phsical activity in epidemiological studies. Am J Clin Nutr [serial online]. 1982 [cited 2014 Jun 5]; 36(5); 936 - 42. Available from http://ajcn.nutrition.org/content/36/5/936.full.pdf+html.

14. Maier W, Buller R, Philipp M, Heuser I. The Hamilton anxiety scale: reliability, validity and sensitivity to change in anxiety and depressive disorders. J Affect Disord [serial on internet]. 1988 Jan-Feb [cited 2014 Jul 6]; 14(1): 61-8. Available from: http://www.jad-journal.com/article/0165-0327(88)90072-9.

15. Baumeister H dan Härter M. Prevalence of mental disorders based on general population surveys. Social Psychiatry and Psychiatric Epidemiology. 2007; 42 (7): 537-46.

16. Widakdo $\mathrm{G}$ dan Besral. Efek penyakit kronis terhadap gangguan mental emosional. Kesmas: Jurnal Kesehatan Masyarakat Nasional. 2013; 7 (7): 309-16. 
17. Phillips S, Sen D, McNamee R. Prevalence and causes of self-reported work-related stress in head teachers. Occupational Medicine. 2007; 57: $367-76$

18. Ireton HR, LaFond N, Kunian A. Personal stress inventory in the screening and evaluation of family practice patients. Fam Pract Res J [serial on internet]. 1989 Spring-Summer [cited 2014 Jul 12]; 8(2): 62-74. Available from: http://psycnet.apa.org/psycinfo/1990-26414-001

19. Harris OJ, Hartman SJ.Organizational behavior. New York: Best Business Books; 2002.
20. Ngidi DP, Sibaya PT. Black teachers' personality dimensions and workrelated stress factors. South African Journal of Psychology. 2002; 32 (3): 7-16.

21. Mkumbo, Kitila. Prevalence of and factors associated with work stress in Academia in Tanzania. International Journal of Higher Education. 2014; 3 (1): 1-11.

22. Palos R, Vîscu L. Anxiety, automatic negative thoughts, and unconditional self-acceptance in rheumatoid arthritis: a preliminary study. ISRN Rheumatol. 2014; about 4 pages. DOI:10.1155/2014/317259. 